\title{
The Impact of the World Food Price Crisis on Nutrition in China
}

Robert T. Jensen and Nolan H. Miller

CID Working Paper No. 176

August 2008

(C) Copyright 2008 Robert T. Jensen and Nolan H. Miller, and the President and Fellows of Harvard College

\section{Working Papers Center for International Development at Harvard University}




\title{
THE IMPACT OF THE WORLD FOOD PRICE CRISIS ON NUTRITION IN CHINA*
}

\author{
Robert T. Jensen \\ UCLA School of Public Affairs \\ and \\ NBER
}

Nolan H. Miller

John F. Kennedy School of Government

Harvard University

\begin{abstract}
World food prices have increased dramatically in recent years. We use panel data from 2006 to examine the impact of these increases on the consumption and nutrition of poor households in two Chinese provinces. We find that households in Hunan suffered no nutrition declines. Households in Gansu experienced a small decline in calories, though the decline is on par with usual seasonal effects. The overall nutritional impact of the world price increase was small because households were able to substitute to cheaper foods and because the domestic prices of staple foods remained low due to government intervention in grain markets.
\end{abstract}

\footnotetext{
* We would like to thank Katie Naeve, Frank Mou, Dulles Wang and Fan Zhang for research assistance. We gratefully acknowledge financial support from the National Institute of Aging, the William F. Milton Fund at Harvard Medical School, the Dean's Research Fund at the John F. Kennedy School of Government, the Center for International Development at Harvard University, and the Hefner China Fund.
} 


\section{INTRODUCTION}

In recent years, there has been a well-documented, dramatic increase in world food prices. From 2006 through early 2008, the FAO Food Price Index increased by 73 percent, with across-the-board increases in meat (16 percent), dairy (100 percent), oils and fats (144 percent) and cereals (129 percent). ${ }^{1}$ Within cereals, the price of rice increased by approximately 117 percent, ${ }^{2}$ wheat increased by 100 percent and maize by 65 percent. ${ }^{3}$ There has been considerable concern that such large price increases may lead to increased malnutrition, especially among the poor in the developing world. However, to date little is known about the nutritional consequences the food price crisis has had.

A number of factors influence the extent to which nutrition declines when food prices increase. Certainly, the increase in prices leads directly to a decline in real purchasing power that makes households worse-off. ${ }^{4}$ However, households may be able to respond to this crisis without reducing nutrition by substituting across foods. For example, households may substitute from more expensive sources of calories to less expensive sources. This may involve substitution across broad food categories (for example, from meat to grains), substitution across foods within broad food categories (ex., from rice to less preferred grains such as millet) or substitution in quality within narrow food categories (for example, from higher to lower quality cuts of meat). However, one potential limitation for the poor in particular is that they are likely to already be consuming the lowest cost foods like grains (for example, in our sample of the urban poor in China, the average household gets nearly three-quarters of their calories from cereals like rice or wheat) and the cheapest variety of those foods. This may leave them little room to substitute in an effort to mitigate the nutritional impacts of the price changes. And what raises particular concern

\footnotetext{
1 Figures reported for March 2008. The price of sugar decreased by 11 percent. See http://www.fao.org/docrep/010/ai465e/ai465e06.htm.

${ }^{2}$ FAO rice price index. See http://www.fao.org/es/ESC/en/15/70/highlight 533.html .

3 See FAO, "Crop Prospects and Food Situation," No. 1, February 2008, Table A1.7, http://www.fao.org/docrep/010/ah881e/ah881e08.htm .

${ }^{4}$ Provided, of course, that the households are net buyers of the items in question. Sellers of commodities whose prices increase are made better off by the change.
} 
with this crisis is not just the magnitude of the price increases, but the fact that they have been across-the-board increases affecting most foods, which further limits the ability to substitute across foods.

The impact of this crisis can only be understood at the level of the individual country. While there have been dramatic increases in the "world" prices of food items, these increases do not necessarily translate directly into equivalent increases in domestic prices. Transportation costs, policies that impose barriers on cross-border trade of commodities, and policies aimed at managing the price or controlling the stock of important commodities can all contribute to the divergence of domestic and world prices. In addition, there has been variation in the extent of the domestic and international price increases across specific foods, and diets vary considerably across countries. The impact of the food price crisis would be expected to be larger in countries that rely more on commodities whose prices have experienced the largest increases.

In this paper, we analyze these issues for China. While the food price crisis has affected many countries, both rich and poor, China represents an important case for study. Despite decades of sustained economic growth, there is still considerable poverty in the country, with over 400 hundred million people living on less than two dollars per person per day. And the Food and Agricultural Organization (FAO) estimates that about 150 million people in China are undernourished (FAO 2006), more than any other country except India. As we detail below, although China has experienced large, across-the-board price increases in food prices since mid2006, due to domestic circumstances and government policies the increase in domestic grain prices has been smaller than the increase in world prices, while domestic meat prices have increased much more than the world prices.

Our analysis documents the impact of the early part of the crisis using panel data from a detailed, multi-round household consumption survey of the urban poor collected between April and December 2006 in two provinces, Hunan and Gansu. The households in our survey are drawn from the urban poor, and thus are likely to be among the most vulnerable households to increases 
in food prices. Beyond being simply the poorest, these households also spend a larger share of their total expenditures on food, so in percent terms, the real wealth shock of the price increases is large. In addition, rural households often produce food either for their own consumption, sale or both. In both cases, they are insulated to an extent from the harmful effects of price increases. Urban households, on the other hand, have no such insurance and thus must bear the full brunt of the food price increases. ${ }^{5}$

A key advantage of our study is that we have data that span the increase in food prices; because the price increases have been so sudden, and because of the time-intensiveness of implementing large-scale, micro-level surveys, there are few household-level data sets in place to analyze the problem, much less with multiple survey rounds surrounding the time of the price increases. ${ }^{6}$ While prices have continued to rise since our data were collected, the price increases during the survey period were substantial, almost one-half of the total domestic price increase in China during the course of the crisis, and thus the data provide an early look at the impact of the burgeoning crisis.

Another key advantage for analyzing the impact of the crisis is that the survey gathered detailed, food intake diaries for each member of the household. These data can be matched to food nutrient tables to directly assess the nutritional impact of the price increases, rather than just consumption changes. For this analysis, we focus on caloric intake as the measure of nutrition, since this is the standard by which under-nutrition is commonly assessed by the FAO and other international bodies. While nutrition is a complex, multi-dimensional variable that can't be proxied by a single measure, caloric intake is clearly critical for overall nutrition. There is a clear relationship between calorie deprivation and health, and there is evidence that when calorie-

\footnotetext{
${ }^{5}$ Friedman and Levinsohn (2002) found that this mechanism led the impact of the 1997 Asian currency crisis to be much larger for the urban poor than the rural poor due to this effect.

${ }^{6}$ Although macro-level estimates of consumption changes for individual countries are available (for example, FAO 2008), these estimates are less reliable than individual-level consumption data and also do not make it possible to analyze the impact for subgroups below the level of the entire economy.
} 
deprived, the body may be unable to absorb other nutrients. And in the case of the very poor, i.e., those who live on the boundary of subsistence, small changes in caloric intake can have a large impact on nutrition, and through it welfare. Further, given the simple diet of extremely poor people in China, it seems unlikely that the food-price crisis would significantly affect overall nutrition without affecting caloric intake. For this reason, caloric intake provides an important first measure of the impact of the crisis.

We find that households in Hunan were able to effectively protect calorie intake during the early part of the food price crisis. Households in Gansu, on the other hand, experienced small decreases in calories (4-5 percent). However, we cannot rule out that this decline is in line with the typical seasonal declines in calorie intake in colder climates like Gansu, driven by increases in heating costs. Thus, the nutritional impacts of the crisis appear to have been quite limited. We argue larger declines were avoided due to households substituting towards cheaper foods, and by government policies that kept domestic grain prices low even as world grain prices skyrocketed. Of course, the lack of nutritional consequences does not imply that there were no welfare consequences of the crisis. Households were still made worse off in terms of purchasing power and real wealth as a result of the price increases, and even substitutions towards lower costs foods represents a decline in welfare, since households derive satisfaction from the non-nutritional attributes (for example taste and variety) of the food they consume in addition to the nutritional attributes.

The remainder of this paper proceeds as follows. In Section II, we discuss our data and the empirical strategy. Section III provides information on changes in domestic food prices in China over this period, using both data from our survey and from official statistics, and provides a description of the government's responses to the world food price changes. Section IV shows the impacts of the crisis on caloric intake and how households adjusted their food and non-food expenditure patterns. Section V concludes. 


\section{DATA AND EMPIRICAL STRATEGY}

\section{A. Data}

The survey was conducted by the provincial-level agencies of the Chinese National Bureau of Statistics. The sample consisted of 100-150 households in each of 11 county seats spread across the provinces of Hunan (Anren, Baoqing, Longshan, Pingjiang, Shimen and Taojiang) and Gansu (Anding, Ganzhou, Kongdong, Qingzhou and Yuzhong in Gansu). The total sample size was 1,300 households (650 in each province), containing 3,661 individuals. Within each county seat, households were chosen at random from lists of the "urban poor" maintained by the local offices of the Ministry of Civil Affairs. Households on this list fall below a locallydefined poverty threshold (the Di Bao line), typically between 100 and 200 yuan per person per month or $\$ 0.41-\$ 0.82$ per person per day, which is less than the World Bank's "extreme" poverty line of one dollar per person per day. Because all of the respondents were residents of cities, typically with populations of at least one million, there was no home production of food, so we do not have to be concerned about any possible wealth effects of the food price increases.

Data were gathered in three rounds, conducted in April, September and December of 2006. In two previous studies (Jensen and Miller 2008a,b), we used these data to analyze the impact of an experimentally induced price subsidy for basic grains (rice in Hunan and wheat in Gansu) on consumption and nutrition. In the present study, our interest is assessing the nutritional impacts of the food price increases over the course of the 8 month data collection period. Since overall time span from the first to the last survey round was fairly short, sample attrition was extremely low, with only 11 out of the 1,300 households (les than one percent) dropping out of the study. We drop these households from our analysis. However, including them does not affect the results appreciably.

The questionnaire consisted of a standard income and expenditure survey, gathering information on the demographic characteristics of all household members, as well as data on employment, income, asset ownership and expenditures. A key component of the survey was a 
24-hour food recall diary completed by each household member. Respondents were asked to report everything they ate and drank the previous day, whether inside or outside the home, by specifically listing the components of all foods eaten. These foods were recorded in detail in order to match with the 636 detailed food items listed in the 1991 Food Composition Tables constructed by the Institute of Nutrition and Food Hygiene at the Chinese Academy of Preventative Medicine. We convert food consumption into calories using the nutritional information contained in the Food Composition Tables.

In addition to the household survey, for each round we conducted a survey of market prices in each of the survey counties, gathering data on the prevailing price for 39 individual food items. These items constitute the overwhelming bulk of foods consumed by households in our sample and thus allow for a useful gauge of the price changes they faced during this period. We also note that while some foods such as rice are commonly available in varying degrees of quality and price, most of the households in our sample of impoverished households were consuming only the cheapest varieties, so there is no ambiguity in assigning prices to the goods.

\section{B. Empirical Strategy}

Our analysis will focus simply on comparing prices and nutrition across the survey rounds. For this purpose, we use only the first and last rounds of the survey in order to eliminate any impact of our experimental price subsidy. Respondents in our study were divided into four equally sized groups, three receiving different subsidy levels, and one receiving no subsidy. The subsidy ran from April to October. The first survey round was conducted before respondents started receiving the subsidy, or were even aware they would receive it. The third round was conducted 1 to 2 months after the subsidy had ended, by which time treatment households would have exhausted any stocks of rice or wheat flour they may have purchased with the subsidy, and were therefore again purchasing all their foods at the full market price. Using the full sample substantially increases the precision of our estimates. Given this, and the fact that the final round 
of the survey was conducted well after the conclusion of the intervention, we have chosen to base the analysis in this paper on the entire sample. However, using just the control group that received no subsidy (in order to be more certain the subsidy had no impact on nutrition) yields similar results for all that follows, though the coefficients are somewhat less precisely estimated due to smaller sample sizes. ${ }^{7}$

The biggest challenge to this approach is that we are using surveys gathered in different months (April and December). This can affect our analysis in two ways: seasonality in prices and seasonality in consumption or nutrition independent of price. On the first of the two, the concern is that if food prices regularly increase in winter, we would be unable to distinguish how much of the overall measured food price changes are attributable to the food price crisis and how much is just due to any usual seasonal patterns in prices. To an extent, this does not affect our analysis. Our interest is in simply asking, what were the nutritional consequences of the large increase in food prices observed over this eight month period, regardless of the source of that increase. We might be concerned that some of the consumption changes we observe could be driven by the lack of availability of certain foods in one of the two periods in our sample (e.g., if pork consumption were lower in December than April because pork were not available). However, there is no evidence of seasonal stock-outs among grains and meat, the goods that were most widely consumed. ${ }^{8}$ Therefore, any changes in consumption and nutrition we observe are not driven by changes in the availability of different foods, only their prices, so our exercise still validly assesses the impact of the substantial increase in prices over this period on household nutrition. ${ }^{9}$

\footnotetext{
${ }^{7}$ Results using only the control group are available from the authors.

${ }^{8}$ There may be some seasonal variation in the types of fruits or vegetables available, however in many cases close substitutes (with comparable cost and nutritional content) are available. Further, such foods constitute only a very small fraction of the total diet of the households in our sample.

${ }^{9}$ In contrast, it would be problematic if there were seasonal changes in taste that affected households' willingness to pay for various foods.
} 
However, one concern in not being able to separate the observed price changes into a seasonal component vs. an increase due to the world food price crisis is that households may be able to respond better to the seasonal price changes because it is predictable, whereas the crisisinduced increase was not. Therefore, assessing the change in calories associated with the overall price change may understate the nutritional consequences of the secular price change. In other words, a true, unobserved increase in prices associated with the global price crisis would likely have a bigger impact than what we measure because it was not predicted, unlike a component of our measured price change, which was predictable and for which households were able to prepare (perhaps, for example, by storing foods for winter). Unfortunately, we are not able to overcome this limitation of the data. However, we are not aware of any study suggesting there are large seasonal price fluctuations in China, especially for the foods which dominate the diet of the average low-income household (such as grains). While there may perhaps be more seasonality in the prices of certain fresh fruits or vegetables, these foods do not contribute significantly to nutrition in our sample (as will be shown below).

The second concern is whether there are seasonal consumption or demand patterns, so that food and nutrition would differ in the two rounds even without the food price changes. The biggest factor to consider is heating costs due to seasonal temperature differences. ${ }^{10}$ Gansu in particular has very cold winters, with average daily December high temperatures of 30-35 degrees Fahrenheit and average lows of 10-15 degrees. By contrast, the average high and low temperatures in Gansu in April are 65-75 degrees and 35-45, respectively. Therefore, we might expect relatively higher heating and/or utilities demand in the third round than the first round of our survey, which could affect consumption independent of changes in food prices. This is perhaps less of a concern in Hunan, which has somewhat mild winters, with average December highs of 50-55 degrees and average lows of 40-45 degrees (with April temperatures averaging 65-

\footnotetext{
${ }^{10}$ Though it is also possible for example that consumption and calorie intake are lower in winter simply because people engage in less physical activity (resulting for example from less labor activity for workers in sectors such as construction).
} 
70 degree highs and 50-55 degree lows). Thus, not only are Hunan winters warmer, but the AprilDecember spread in average temperatures is small (15 degrees) compared to the spread for Gansu (30 degrees).

Studies for the United States find that caloric intake does decline among poor households during winter months because of higher fuel costs (Bhattacharya et. al 2008), but we are not aware of any studies that have investigated this issue in China. However, in order to interpret the nutrition changes we observe later, it is important to explore this issue further. While our data cannot address this issue directly, we can provide some evidence on potential baseline seasonal nutrition patterns using data from the 1997, 2000 and 2004 rounds of the China Health and Nutrition Survey (CHNS), ${ }^{11}$ a panel survey gathered by the Carolina Population Center at the University of North Carolina at Chapel Hill, the Institute of Nutrition and Food Hygiene and the Chinese Academy of Preventative Medicine. The sample consists of approximately 16,000 individuals in 3,800 households in each round, drawn using a multi-stage, random cluster strategy for 9 of China's provinces. ${ }^{12}$ The CHNS gathered information on foods eaten via a three day consumption diary, which can be converted to nutrient intakes using the same 1991 Chinese Food Composition Table as we use for our data. For our purposes, one attractive feature of the CHNS is that the data collection in each survey year was spread over many months, typically from September to December. ${ }^{13}$ In many cases, even within individual provinces the surveys often stretched over three months in each survey year, so that it is not the case, for example, that monthly variation in the survey date will only capture province-level differences in caloric intake. We can use the variation in survey date in the CHNS to analyze whether, in earlier years before

\footnotetext{
${ }^{11}$ While the CHNS also has survey rounds in 1989, 1991 and 1993, we focus only on the most recent rounds since there may have been other significant changes in the 15 years since 1993 (for example, prior to 1993, some grains were still provided in the form of rations or at subsidized prices from state-run stores). The CHNS also has a survey round from 2006, but this overlaps with the food price increase and therefore does not help us estimate seasonality prior to the crisis.

${ }^{12}$ The data and additional information can be found at http://www.cpc.unc.edu/china.

${ }^{13}$ In many cases, even within individual provinces the surveys often stretched over three months in each survey year, so that it is not the case, for example, that monthly variation in survey date may capture province-level differences in caloric intake.
} 
the current world food price crisis, there are observable declines in caloric intake during the colder, winter months.

Using the CHNS, we estimate regressions where individual level calorie intake is regressed on a series of month indicators, with survey year and province dummy variables added as additional controls. Table 1 provides the results. For the full sample of provinces in column 1 , we find no evidence of seasonal nutrition declines. Calorie intake is essentially equal in September and December. However, the CHNS includes several provinces that also have moderate winters (including Hunan). In column 2, we limit ourselves to the 5 northernmost provinces in the sample (Heilongjiang, Henan, Liaoning, Jiangsu and Shandong), which have colder winters. Here we find that in fact calorie intake declines as the weather gets colder. ${ }^{14}$ Relative to September averages, individual caloric intake declines on average by 13 calories in October, 51 calories in November, and 69 calories in December (though only the latter two are statistically significant). While this method is not ideal, the results do suggest that, consistent with the study for the United States, nutrition does decline in December in colder provinces. We will consider 69 calories per person to be an approximate baseline against which to compare the results on nutritional changes in Gansu, whereas the changes in Hunan can be interpreted on their own since there is no evidence of seasonal patterns for provinces with more mild winters.

While our approach is not ideal, we note that in general, there is no ideal way to isolate the impacts of the food price crisis on nutrition. The primary price variation of interest is timeseries variation, so the only form of analysis suitable for this purpose is comparisons over time. But the crisis has only been in effect for at most two years. So any analysis is bound to conflate time effects with price effects. Even having surveys conducted in the same season or month in consecutive years does not solve the problem, since seasonal costs may vary from year to year

\footnotetext{
${ }^{14}$ The average daily high and low December temperatures for these provinces are: Heliongjiang (10-15, -50 ), Liaoning (30-35, 10-20), Shandong (40-45, 25-30), Jiangsu (45-50, 30-35), Henan (45-50, 25-30), Hubei (50-55, 35-40), Guizhou (50-55, 40-45), Hunan (50-55, 40-45), and Guangxi (65-70, 45-50). All data drawn from Tao et. al (1991).
} 
(for example, there may be a particularly cold winter one year but not the next). However, we believe there is value in simply comparing how nutrition changed over this period, taking into consideration the limitation that we cannot distinguish seasonal effects from the net effects of the overall food price increases (which include both seasonal and crises-induced components). Again, while seasonal effects appear to be minimal in Hunan, in Gansu ignoring them may lead us to overstate the consequences of the crisis.

\section{THE FOOD PRICE CRISIS IN CHINA}

Table 2 presents changes in China's Consumer Price Index (CPI) and its various components from June 2006 to June 2008 from official data released by the Chinese National Bureau of Statistics. During this two year period alone, China's overall food CPI increased by a substantial 31 percent. While the price increases for grains, which comprise the bulk of the diet of poor Chinese households, were modest (15 percent), there were much larger increases for meat and poultry (73 percent), eggs (39 percent) and seafood (25 percent). Some of these domestic price changes were brought about by changes in world food prices, about which much has been written (ex., FAO 2008a, World Bank 2008), and which have generally been attributed to factors such as increased demand for grains by the biofuel industry, critical shortfalls in important producers like Australia and Canada, declines in the stocks of cereals held by governments, increased production costs (due for example to increased fuel and fertilizer costs) and rising incomes in countries like India and China leading to increased demand.

Other factors have been more specific to China. For example, the increase in the price of pork was particularly large due to an outbreak of "blue-ear" disease in 2006 that sharply reduced supply. ${ }^{15}$ The grain price increases, while still substantial, were significantly less than the dramatic 129 percent increases in world market prices noted above. The divergence between the

\footnotetext{
${ }^{15}$ The price of pork increased 59.8 percent from June 2006 to June 2007 and 30.4 percent from June 2007 to June 2008. Source: National Bureau of Statistics of China.
} 
world and domestic price increases is substantial. The primary explanation for this divergence appears to be government policies that moderated domestic grain price increases, including the release of grain from government grain stocks and introduction of export controls such as quotas and increased tariffs (Huang, Qiu and Rozelle, 2008), policies that have also been introduced in a number of other countries in response to the crisis. For example, in December of 2007, the government lifted a 13 percent export tariff rebate, and then in January of 2008 imposed additional tariffs of 5 to 25 percent. ${ }^{16}$ Since China is a large producer of grains, with annual production of about 500 billion kilograms, ${ }^{17}$ making the country about 95 percent self-sufficient and the world's largest exporter of grains such as rice, and holds significant grain stores (estimated to be as much as 29 percent of annual production for grains such as rice at the time of the crisis (USDA 2006)), these actions were able to have a significant impact on moderating domestic price increases.

Table 3 shows price changes from our market price survey, which clearly track the start of the general increase in food prices during the latter half of 2006. The overall price increase for staple foods over this 8 month period was, as above, fairly small. In Hunan, rice (the dominant staple) increased by 5 percent, while wheat prices actually declined. In Gansu, wheat (the dominant staple) also increased by 5 percent, while rice prices increased by 3 percent.

By contrast, there were extremely large price increases for meat. Pork, the primary meat consumed in China, increased in price by 38 percent in Hunan and 21 percent in Gansu. While, as mentioned, a portion of this increase was due to a large loss of supply due to blue-ear disease, meat-price increases were not limited to pork. The prices of alternatives such as eggs, chicken and beef increased by $17-46$ percent in Hunan (though fish did decline in price slightly), and by $13-25$ percent in Gansu (with fish increasing by 29 percent). By contrast, the prices of pulses

16 See "Government Sets Export Tariff on Grains," China Daily, January 2, 2008. http://www.chinadaily.net/china/2008-01/02/content_6365352.htm.

${ }^{17}$ In fact, part of the high level of production can itself also be attributed to government policy, which provides subsidies for cereal producers. 
including tofu and beans, often a substitute but less expensive form of protein, increased by $11-$ 18 percent in Hunan, but only 1 and 11 percent respectively in Gansu.

In Hunan, the prices of important vegetables such as spinach, cabbage and lettuce increased by $9-58$ percent. Even some less highly consumed vegetables such as eggplant, onions, tomatoes and peppers experienced price increases of $16-30$ percent (mushrooms, on the other hand, did not change much at all). In Gansu, price changes were more variable. Spinach and cabbage actually declined slightly in price, while lettuce increased by 33 percent. Other vegetables, such as eggplant, tomatoes, mushrooms and peppers increased in price by $23-44$ percent, while most strikingly onions more than doubled. Finally, edible oil, used especially in cooking, increased by 31 and 21 percent in Hunan and Gansu, respectively.

Thus, while the experiences of the two provinces differed slightly, and while each province did not experience uniform price changes, overall, these two provinces experienced dramatic food price increases that are likely to may have consequences for well-being. We also note that while our survey spanned only the beginning part of the crisis, as a rough approximation, the 8 months spanned by our survey captured about one-third to one-half of the total 2006 to 2008 price surge observed nationally for most foods in table 2 .

\section{Food Consumption Patterns}

Since the degree of price increase varied so widely across foods, in order to begin to assess the potential nutritional consequences, it is worthwhile to explore basic consumption patterns in our sample. Table 4 provides information on both the quantity consumed and calorie shares derived from various food aggregates. In both provinces, consumption is dominated by cereals, though there are regional taste preferences, with rice the preferred staple food in Hunan and wheat preferred in Gansu. In Hunan, the average per capita consumption of rice per day is $330 \mathrm{~g}$, comprising 64 percent of daily caloric intake. Wheat and other cereals add another $43.5 \mathrm{~g}$ of daily consumption per person on average, comprising an additional 8 percent of total caloric 
intake. In Gansu, wheat-based foods (primarily noodles, buns and a simple, home-made bread called $\mathrm{mo}$ ) are the dominant staple, with $344 \mathrm{~g}$ of consumption per person per day, comprising 69 percent of total calories. Rice and other cereals add another $39 \mathrm{~g}$, comprising 8 percent of total calories. Thus in both provinces, grains are a dominant source of calories for most households. The total calorie share from all cereals or grains is 72 percent in Hunan and 77 percent in Gansu. The reliance on these basic foods for nutrition is underscored even more by the fact that in both provinces, on average 13 percent of calories come from edible oils (mostly vegetable oil), which is primarily used in cooking (and is generally not a substitute for other forms of consumption or nutrition). Thus, the consumption of all other foods combined on average contributes only 10 percent of calories in Gansu, and 15 percent in Hunan. As noted above, the prices of these staples increased only slightly, at most 5 percent during this 8 month period (and only slightly more over the combined two year period, as indicated in table 2). This already suggests that to the extent that the food price crisis as experienced in China (where domestic prices deviated from world prices, especially for grains) did not as adversely affect the foods eaten as staples, the nutritional impacts may be more limited. That being said, it must be kept in mind that for these extremely poor households, even a 5 percent price increase may represent a large loss of purchasing power.

In both provinces, vegetables and fruit (predominantly cabbage in Hunan, and cabbage and potatoes in Gansu) are the second largest category of consumption based purely on quantity or bulk. Though overall, they contribute little to caloric intake (5 percent in Hunan and 7 percent in Gansu) due to the very low caloric value per gram of these foods. The remaining consumption of meat (primarily pork), pulses (primarily bean curd or tofu) and dairy (primarily milk) constitute about 10 percent of calories in Hunan and 4 percent in Gansu. In Hunan, the greatest share comes from meat, with 42 grams of consumption per person per day on average, comprising 7 percent of average caloric intake. By contrast, in Gansu meat consumption is significantly lower, averaging only 13 grams per person per day and contributing less than 1 percent of total caloric intake. Consumption of pulses is in fact greater than consumption of meat 
in Gansu. This is likely due to the lower levels of income in Gansu; pulses are often referred to as "poor man's meat" because they are a cheaper source of protein (when combined with other foods typically eaten as staples).

\section{NUTRITIONAL IMPACTS AND HOUSEHOLD RESPONSES}

\section{IV.A. Nutrition}

Table 5 provides means and tests of equality of the means for household per capita nutrient intake in the two rounds. Results using regressions to control for changes in household income and demographic composition yield similar results, so since it is valuable to assess any changes in the context of baseline nutritional status, we simply show the levels in both periods and the raw, unadjusted changes in means. Focusing first on Hunan in the top panel, in column 1 we see that calorie intake per capita did not decline at all. The difference in nutrient levels between the two rounds is in fact positive, though extremely small (6 calories) and not statistically significant.

By contrast, for Gansu, there are statistically significant reductions in the average per capita calorie intake. Calories per capita declined overall by 81 , or 5 percent of the first round level. This is a small or moderate loss, made perhaps slightly worse by the fact that the average person is already undernourished by international standards (for example, the mean calorie intake among working-aged adults $(17-60)$ is 2,006 kcal for men and 1,682 for women (see columns 4 and 5). While we can't rule out some undercounting of calories, these values are below international standards). ${ }^{18}$ However, it is important to keep in mind that above we observed in the CHNS that calories tend to decline in December even in previous years with the absence of large food price increases. Viewed in this context, the change in calories in our sample is no different

\footnotetext{
${ }^{18}$ The FAO/WHO/UNU Expert Consultation on Energy and Protein Requirements suggests approximate daily energy requirements ranging from 2,335-3,164 kcal (depending on level of physical activity) for men and 1,846-2,154 kcal for women. In both cases, these requirements are for the "lowest acceptable" body weight (54kg or 119 pounds for men, and $47 \mathrm{~kg}$ or 103 pounds for women).
} 
than the decline expected due to seasonal factors alone (estimated at 69 calories above). In other words, we cannot rule out that the food price increase did not lead to a significant decline in caloric intake.

Although we are already focusing exclusively on households officially classified as falling below the poverty threshold, we can ask whether the overall effects we observe mask larger declines for the poorest of the poor. In figure 1, we show the results of estimating the change in calories per capita as a function of $(\log )$ expenditure per capita in round 1 using a locally-weighted regression smoother (Fan 1992). The top and bottom lines in each graph represent bootstrapped 95 percent confidence intervals. Perhaps contrary to expectations, we find that in both provinces, wealthier households experienced larger declines in calories per capita. However, this relationship is not statistically significant at any point in the distribution of income in Hunan, and in Gansu, the relationship is fairly flat, with the wealthiest households only reducing their caloric intake by slightly more than the poorest households (though because the wealthy consume more calories on average, in percent terms the declines do not differ as much).

While wealthy households spend a smaller share of their budget on food in both provinces and thus might be expected to be able to buffer better against the price increases, wealthy households also consume more meat. For example, in Hunan, households above the (Hunan-specific) median first round expenditure per capita consume on average 60 grams of meat per person per day, whereas those below the median consume only 34 grams. Similarly, in Gansu, households above the first round median per capita expenditure consume on average 17 grams of meat, compared to only 8 grams for those below the median. Given that meat had among the greatest price increases in both provinces, the real wealth shock to wealthier households was greater. However, again, it must be noted that the difference in calorie declines for the two groups are not great in either province. The important observation is that the poorest households did not experience large declines in calories in either province. While point estimates suggest wealthier households may have experienced slightly larger declines, these households are far more nutrient 
secure, consuming on average 100 calories per person per day more than their poorer counterparts within both provinces. Overall, therefore, at the household level we conclude that the loss of caloric intake was not great, nor did it even fall more acutely for the poorest of the poor.

\section{IV.B. Intrahousehold Allocation}

A second possible concern is whether the lack of significant declines in calorie consumption measured at the household level masks losses by particular demographic groups. In particular, there is a large literature on the intrahousehold allocation of resources, for example testing whether girls receive less than boys (see for example Behrman 1988 and Behrman and Deolalikar 1990). We might then ask, for example, whether vulnerable groups such as girls or women suffered as a consequence of the food price crisis. Similarly, it may be that households reallocated resources away from elderly members who have weaker bargaining power because of lower earnings. Or it may be that households choose to reallocate resources away from all adults in order specifically in order to buffer or strengthen the consumption of children, since they are at a critical stage of human development where calorie shortfalls can be more damaging.

Columns 2 through 7 of table 5 show the means of individual-level caloric intake for various age-sex groups in the two rounds. Overall, for Hunan, there is no evidence of decline in nutritional status over this period for any group. In fact, every group experienced an increase, with particularly large increases for both boys and girls. However, none of these changes is statistically significantly different from zero.

In Gansu, we see that caloric intake did not decline at all for boys or girls. Instead, it appears that all of the declines at the household level (which again, are largely seasonal and not due to the price crisis) were driven by declines for adults (there is also some suggestive evidence of declines for the elderly, though the point estimates are much smaller and the coefficients are imprecisely estimated due to small sample sizes). Thus, households were able to buffer the calorie intakes of children. Interestingly, there is no evidence of any differential treatment of boys and 
girls. In fact, the point estimates for girls are positive, while those for boys are negative (though we cannot reject equality of the two, and it should be pointed out that intake is $100-130$ calories lower for girls on average). This stands in contrast to the literature suggesting a preference for boys over girls in the intrahousehold allocation of resources, which is often found to become even more pronounced during an adverse economic event such as large food price increases (ex., Behrman 1988).

\section{IV.C. Patterns of Food Substitution}

The literature on the income elasticity of demand for calories emphasizes that when able, consumers may substitute towards foods with higher non-nutritional attributes or seek to add variety to their diet (see for example Deaton, 1997, chapter 4, and Strauss and Thomas, 1995). In table 6, we consider changes in consumption of various food aggregates to explore how households responded to the food price crisis.

For Hunan, the largest observed changes are an increase in cereal consumption (largely rice) by 22 grams per person per day (6 percent), and a decrease in the consumption of meat and dairy (6.5 grams or 14 percent) and fats (4.2 grams or 16 percent). For Gansu, the pattern was different. Consumption of cereals decreased by $27 \mathrm{~g} /$ person/day ( 7 percent), while consumption of pulses and fruits and vegetables increased by $8 \mathrm{~g} /$ person/day (22 percent) and $34 \mathrm{~g} / \mathrm{person} /$ day (15 percent) respectively.

The different patterns of substitution in the two provinces are likely explained by differences in price changes observed in table 3. In Gansu, the price of pulses, especially bean curd (which is more widely consumed than beans), did not increase much, making them a relatively less expensive source of calories relative to cereals than they were before the price increases. In Hunan, the prices of both meat and pulses increased substantially, causing households to substitute towards cheaper sources of calories, particularly cereals like rice. 
Thus, on top of domestic food prices not increasing dramatically due to government grain market interventions, the evidence suggests that households were further able to minimize the nutritional consequences of the food price crisis by substituting towards foods whose prices increased the least.

\section{IV.D. Patterns of Expenditure Substitution}

Another way in which households might respond to the food price crisis is by altering their total budget, perhaps allocating away from non-food expenditures and towards food in order to maintain nutrition. Table 7 provides data on monthly per capita expenditures by major categories for the two rounds.

In Hunan, food expenditure is largely unchanged over this period despite the increase in food prices. This is presumably as a result of reallocating the food budget, especially moving away from meat, one of the most expensive sources of calories, as seen in Table 6. There is a slight increase in fuel and utility expenditures in the second round due to the slightly colder weather, but the change is small. In addition, there is a slight decline in clothing and entertainment expenditures, perhaps to compensate for the higher fuel and utility costs. However, overall, the changes are very small. There are large apparent increases in average expenditures on health and schooling, however these means are highly variable, skewed in most cases by a few large values (whereas expenditures for the majority of households is zero), so the change between the two rounds is not statistically significant.

By contrast, the budget shifts are greater in Gansu. In particular, food expenditure per capita increased by 4.9 yuan due to the overall price increases. Since households were already consuming primarily only the least expensive foods (grains), with for example little meat consumption before the crisis, there were fewer substitution possibilities available to avoid the price increase. However, precisely because they were consuming primarily grains, the increase in expenditures was not dramatic, because the grain price increases were not particularly large. 
Most notable, and of most concern, is the large decline in health expenditures between the two rounds in Gansu. However, it is unlikely the increase in food prices can account for much of this decline, since health expenditures declined by almost 13 yuan per person, whereas food expenditures increased only by 5 yuan. In fact, the nearly 12 yuan increase in fuel costs, again related largely to the cold weather in December, ${ }^{19}$ is much greater than the increase in food costs and is likely to have been a greater determinant of the declines in health expenditures.

\section{DISCUSSION AND CONCLUSION}

We find that, at least in its early stages, the world food price crisis had little to no impact on the nutrition of the poor in the two provinces we surveyed. However, this does not mean that the crisis is not of concern. The large price increases represent a large loss of real purchasing power and wealth for these households. While households were able to buffer this shock, at least in the short run, the somewhat muted effect of the crisis on nutrition is due in part to shifts in household budgets, both to less expensive food categories and perhaps to an extent from non-food expenditures to food. Thus, while a decrease in nutrition is a strong indicator of short-term harm, its absence should not be interpreted as suggesting the crisis is having no impact on welfare.

The lack of any strong nutritional consequences for the case of China in particular is perhaps not surprising. Quite simply, poor households in China rely on basic cereals such as rice and wheat for the overwhelming bulk of their diet, and the country was effectively able to insulate itself against domestic grain price increases through a number of current and past public policy measures, including pursuing a policy of encouraging supply aimed at grain selfsufficiency, maintaining unusually large government stocks of grains and deploying them when necessary, and limiting exports through the imposition of quotas and taxes. ${ }^{20}$ However, it should

\footnotetext{
${ }^{19}$ Aside from the actual increased use of heating fuel (primarily coal), there may have also been an increase in price. Unfortunately, our survey did not gather information on fuel prices.

${ }^{20}$ See "The ravening hoards: no need for alarm; but some Chinese ring bells anyway," The Economist, 19 April 2008: 54.
} 
be noted that the ability of these policies to control grain prices in the long run is less certain, especially as stocks are run down, and there are already some signs of increased grain-price inflation in 2008 (Huang, Qiu and Rozelle, 2008).

The two underlying characteristics that have allowed China's poor to avoid severe nutritional consequences of the sharp increase in world food prices - consumption that is dominated by grains and being a large producer of grains - are likely to be found in many other countries as well. For example, households in India consume a large share of their calories from rice and wheat and the country is a large producer of both. Like China, by limiting exports, India has also been able to moderate food price increases, which were only 6 percent between March 2007 and March 2008 (World Bank 2008). Similar cases of high production, high consumption countries include Thailand and Vietnam, who traditionally are the largest exporters of rice. Thus, rather than being unusual, China is largely to be reflective of the impact of the crisis for a large number of countries.

However, the very same strategy of export-limitation that has enabled large producers to avoid sharply increasing domestic food prices is likely to hurt lower-income countries whose diets are primarily concentrated on grains and who are highly dependent on grain imports, such as Nepal, for example. Countries such as these are likely to face very high increases in domestic food prices, perhaps close to the international prices, which in turn are being driven up by the reduction in supply to world markets by countries like China. It is perhaps on countries such as this (high consuming, high importing countries) that more international attention and resources should be focused during the food price crisis.

One commonly-mentioned response to the worldwide food-price crisis has been the introduction or extension of food price controls and/or subsidy policies. However, recognizing that there were little to no adverse nutritional consequences suggests that a wider range of policies, beyond those focused purely on addressing nutritional status, should be considered in response. To the extent that we measured harm in our data, it was in reduced expenditures on 
health in Gansu, and nutritional support policies will not directly address this. That being said, food price subsidies may still prove valuable, perhaps because they are easier to target than other policies, and food aid, to the extent that it frees up income to be spent on other goods, may moderate the impact of the food price crisis on other expenditure areas as well.

Finally, we should point out a few limitations of our study. First, we can only analyze the short-run impacts of the food price crisis. However, whether the longer-term will reveal more adverse impacts is ambiguous. Households may either be better or worse suited to coping in the medium and longer run. On the one hand, if household are drawing down their savings (either formal or informal), we might expect the long-run impact of the price increases to be larger than we observe. However, we find no evidence of any reductions in savings (since savings were already so low in the early period, and households are unlikely to have had access to credit to increase debt to cope with the crisis). And in the opposite direction, households' ability to cope may increase in the long run, as they may find alternative foods to substitute towards (for example, different grains like millet), find new places to purchase food at lower prices, adjust their labor supply to increase earnings, or begin to produce some food at home in small gardens.

Further, since prices rose further after the completion of our survey, there may be a greater response than what we have measured as of the end of our survey. However, evidence suggests that even with the more recent price increases, there have not been declines in, for example, grain consumption in a number of countries (FAO 2008b, p. 29-30). ${ }^{21}$ Further, while there are some persistent trends in structural factors that have contributed to the overall increase in prices over the past few years, there is mixed evidence on whether the larger, more recent spikes are transitory or permanent. In fact, there is already evidence that grain prices have fallen considerably (in some cases, as much as 40 percent) from mid-2008 peaks (FAO 2008b, Barta and Lyons 2008), though the prices still remain much higher than their pre-crisis levels. And we

\footnotetext{
${ }^{21}$ However, data from studies like this must be interpreted cautiously because they are based on macrolevel, supply-methods rather than household data.
} 
should also note that for the case of China, domestic food prices have not grown that much more rapidly in the period after our analysis (as seen in table 2).

A second limitation is that we examine only the poorest households in China. There is of course reason to be more concerned with these households than with wealthier households. And we did find to an extent slightly greater calorie declines among the wealthier of the urban poor. However, it seems likely the impact on nutrition for even wealthier households will be smaller. First, food is on average a smaller share of the total household budget for wealthier households, so the impact of price changes have a smaller impact on real purchasing power. Second, many of the poorest households were already consuming most of their calories from the cheapest calorie sources (cereals), and within food categories such as cereals or meat they were already choosing the cheapest varieties. For wealthier households, they are likely to be able to substitute toward less expensive varieties, or foods with lower processing, packaging and other amenities, which might mean the nutritional consequences for them are even smaller.

\section{REFERENCES}

Barta, Patrick and John Lyons (2008). "Falling Commodities Prices Ease Fears of Inflation in Developing Countries,” the Wall Street Journal, August 18, 2008.

Bhattacharya, Jayanta, Thomas DeLeire, Steven Haider and Janet Currie (2003). "Heat or Eat? Cold-Weather Shocks and Nutrition in Poor American Families," American Journal of Public Health, 93(7), p. 1149-54.

Behrman, Jere R. (1988). "Intrahousehold Resource Allocation of Nutrients in Rural India: Are Boys Favored? Do Parents Exhibit Inequality Aversion?” Oxford Economic Papers, 40(1), p. 32-54.

- - and Anil Deolalikar (1990). "The Intrahousehold Demand for Nutrients in Rural South India:

Individual Estimates, Fixed Effects and Permanent Income," the Journal of Human Resources, 25(4), p. 655-696.

Deaton, Angus (1997). The Analysis of Household Surveys: A Microeconomic Approach to Development Policy. Baltimore, Maryland: The Johns Hopkins University Press. 
Fan, Jianqing (1992). "Design-Adaptive Nonparametric Regression," Journal of the American Statistical Association, 87, p. 998-1004.

Food and Agricultural Organization (2006). The State of Food Insecurity in the World, 2006. Rome.

- - (2008a). Soaring Food Prices: Facts, Perspectives, Impacts and Actions Required. High Level

Conference on World Food Security. Rome, Italy: FAO.

- - (2008b). Asia Pacific Food Situation Update. Rome, Italy: FAO.

Friedman, Jed and James Levinsohn (2002). “The Distributional Impacts of Indonesia's Financial Crisis on Household Welfare: A "Rapid Response" Methodology." World Bank Economic Review, 16(3), p. 397-423.

Huang, Jikun, Huanguan Qiu and Scott Rozelle (2008). "More Pain Ahead for China's Food Prices," Far Eastern Economic Review, 171(5), p. 8 - 13.

Jensen, Robert T. and Nolan Miller (2008a). "Giffen Behavior and Subsistence Consumption," NBER Working Paper No. 13243 (forthcoming, American Economic Review).

-- and -- (2008b). “Do Consumer Price Subsidies Really Improve Nutrition?” Faculty Research Working Paper RWP08-025, John F. Kennedy School of Government, Harvard University. Ravallion, Martin (2007). "Geographic Inequality in a Decentralized Anti-Poverty Program: A Case-Study of China,” World Bank Policy Research Working Paper No. 4303.

Strauss, John and Duncan Thomas (1995). "Human Resources: Empirical Modeling of Household and Family Decisions," in Behrman, Jere R. and T.N. Srinivasan, eds., Handbook of Development Economics, Volume 3, Amsterdam: North-Holland.

Tao Shiyan, Fu Congbin, Zheng Zhaomei and Zhang Qingyun (1991). Two Long-Term Instrumental Climactic Data Bases of the People's Republic of China. ORNL/CDIAC-47, NDP-039. Carbon Dioxide Information Analysis Center, Oak Ridge National Laboratory, Oak Ridge, Tennessee.

United States Department of Agriculture (2006). World Agricultural Supply and Demand Estimates (WASDE), July. Washington, D.C.: USDA.

World Bank (2008). Guidance for Responses from the Human Development Sectors to Rising Food Prices. Washington, DC: World Bank. 
Table 1. Baseline Seasonal Calorie Changes--CHNS

\begin{tabular}{lccc}
\hline \hline & & & \\
& & Northern & Southern \\
& All Provinces & Provinces & Provinces \\
\cline { 2 - 4 } October & $-38.3^{* * *}$ & -13.4 & $-65.8^{* * *}$ \\
November & $(11.4)$ & $(16.2)$ & $(16.0)$ \\
& $-42.1^{* * *}$ & $-50.6^{* * *}$ & -28.6 \\
December & $(13.8)$ & $(19.4)$ & $(19.9)$ \\
Year=2000 & -1.5 & $-68.7^{* *}$ & 24.2 \\
& $(19.1)$ & $(33.1)$ & $(24.3)$ \\
Year=2004 & $45.2^{* * *}$ & 19.0 & $68.5^{* * *}$ \\
& $(9.8)$ & $(14.2)$ & $(13.7)$ \\
Constant & -7.5 & $-65.7^{* * *}$ & $50.6^{* * *}$ \\
& $(10.3)$ & $(14.8)$ & $(14.4)$ \\
Province Fixed Effects & $2213.0^{* * *}$ & $2188.1^{* * *}$ & $2240.2^{* * *}$ \\
Number of Obs & $(11.1)$ & $(16.2)$ & $(15.3)$ \\
\hline
\end{tabular}

Notes: Data from the China Health and Nutrition Survey (CHNS). The dependent variable in all regressions is the change in caloric intake, measured at the individual level. Regressions also include province fixed effects. The omitted month category is September, and the omitted year indicator is 1997. Standard errors clustered at the household level. *Significant at 10 percent level. ${ }^{* *}$ Significant at 5 percent level. ${ }^{* * *}$ Significant at 1 percent level. 
Table 2. China's Consumer Price Index by Category, June 2008.

\begin{tabular}{lr}
\hline \hline Consumer Price Index (Overall) & 111.8 \\
Food & 130.6 \\
Grain & 115.3 \\
Meat, Poultry and their Products & 172.7 \\
Eggs & 138.7 \\
Aquatic Products & 124.5 \\
Fresh Vegetables & 113.5 \\
Fresh Fruits & 95.7 \\
Tobacco, Liquor and Articles & 104.9 \\
Clothing & 98.2 \\
Household Facilities, Articles and Services & 104.8 \\
Health Care and Personal Articles & 105.1 \\
Transportation and Communication & 97.8 \\
Recreation, Education and Culture Articles & 97.8 \\
Residence & 112.4 \\
\hline June 2006 = 100 & \\
Source: China National Bureau of Statistics, monthly \\
consumer price index by category. The data are available at: \\
http://www.stats.gov.cn/english/statisticaldata/index.htm.
\end{tabular}


Table 3. Market Prices of Basic Foods

\begin{tabular}{|c|c|c|c|c|c|c|}
\hline & \multicolumn{3}{|c|}{ HUNAN } & \multicolumn{3}{|c|}{ GANSU } \\
\hline & April & $\overline{\text { December }}$ & $\%$ Change & April & $\overline{\text { December }}$ & $\%$ Change \\
\hline & \multicolumn{6}{|c|}{ Cereals } \\
\hline Rice & 2.45 & 2.57 & 0.05 & 3.44 & 3.56 & 0.03 \\
\hline Wheat & 2.87 & 2.71 & -0.05 & 2.06 & 2.17 & 0.05 \\
\hline \multicolumn{7}{|l|}{ Meat } \\
\hline Pork & 10.58 & 14.58 & 0.38 & 10.28 & 12.48 & 0.21 \\
\hline Eggs & 7.80 & 11.42 & 0.46 & 5.31 & 7.00 & 0.32 \\
\hline Chicken & 14.37 & 17.17 & 0.19 & 10.40 & 12.96 & 0.25 \\
\hline Fish & 7.87 & 7.57 & -0.04 & 10.20 & 13.12 & 0.29 \\
\hline Beef & 17.07 & 20.00 & 0.17 & 16.76 & 18.96 & 0.13 \\
\hline \multicolumn{7}{|l|}{ Pulses/Beans } \\
\hline Bean Curd & 2.25 & 2.65 & 0.18 & 2.50 & 2.52 & 0.01 \\
\hline Flat Beans & 1.47 & 1.63 & 0.11 & 1.80 & 2.00 & 0.11 \\
\hline \multicolumn{7}{|l|}{ Vegetables } \\
\hline Spinach & 2.04 & 3.02 & 0.48 & 2.52 & 2.40 & -0.05 \\
\hline Cabbage & 1.27 & 1.38 & 0.09 & 1.34 & 1.16 & -0.13 \\
\hline Lettuce & 1.42 & 2.23 & 0.58 & 2.08 & 2.76 & 0.33 \\
\hline Onions & 3.38 & 3.93 & 0.16 & 2.06 & 4.40 & 1.13 \\
\hline Eggplant & 2.88 & 3.73 & 0.30 & 3.16 & 4.12 & 0.30 \\
\hline Mushrooms & 3.93 & 4.00 & 0.02 & 3.30 & 4.75 & 0.44 \\
\hline Potatoes & 2.12 & 1.82 & -0.14 & 1.10 & 1.36 & 0.23 \\
\hline Tomatoes & 3.10 & 3.98 & 0.28 & 2.90 & 3.72 & 0.28 \\
\hline Celery & 2.38 & 2.24 & -0.06 & 1.62 & 1.96 & 0.21 \\
\hline Peppers & 3.17 & 3.77 & 0.19 & 4.30 & 5.28 & 0.23 \\
\hline \multicolumn{7}{|l|}{ Fats } \\
\hline Edible Oil & 7.02 & 9.18 & 0.31 & 7.64 & 9.28 & 0.21 \\
\hline
\end{tabular}

Notes: All prices are in nominal yuan per kilogram. 
Table 4. Daily Consumption Per Capita and Calorie Shares for Food Categories

\begin{tabular}{|c|c|c|c|c|}
\hline & \multicolumn{2}{|c|}{ HUNAN } & \multicolumn{2}{|c|}{ GANSU } \\
\hline & Consumption $(\mathrm{g})$ & Calorie Share & Consumption $(\mathrm{g})$ & Calorie Share \\
\hline Rice & $\begin{array}{c}330 \\
{[125.4]}\end{array}$ & $\begin{array}{l}0.64 \\
{[.17]}\end{array}$ & $\begin{array}{c}35 \\
{[69.5]}\end{array}$ & $\begin{array}{l}0.07 \\
{[.13]}\end{array}$ \\
\hline Wheat & $\begin{array}{c}42 \\
{[60.2]}\end{array}$ & $\begin{array}{l}0.08 \\
{[.12]}\end{array}$ & $\begin{array}{c}344 \\
{[134.3]}\end{array}$ & $\begin{array}{l}0.69 \\
{[.17]}\end{array}$ \\
\hline Other Cereals & $\begin{array}{c}1.5 \\
{[21.3]}\end{array}$ & $\begin{array}{c}0.00 \\
{[.022]}\end{array}$ & $\begin{array}{c}4.2 \\
{[24.2]}\end{array}$ & $\begin{array}{c}0.01 \\
{[.050]}\end{array}$ \\
\hline Vegetables and fruit & $\begin{array}{c}341 \\
{[194.6]}\end{array}$ & $\begin{array}{c}0.05 \\
{[.044]}\end{array}$ & $\begin{array}{c}232 \\
{[141.6]}\end{array}$ & $\begin{array}{c}0.07 \\
{[.045]}\end{array}$ \\
\hline Meat (incl. eggs) & $\begin{array}{c}47 \\
{[68.6]}\end{array}$ & $\begin{array}{l}0.07 \\
{[.11]}\end{array}$ & $\begin{array}{c}13 \\
{[30.1]}\end{array}$ & $\begin{array}{c}0.01 \\
{[.037]}\end{array}$ \\
\hline Pulses & $\begin{array}{c}62 \\
{[102.3]}\end{array}$ & $\begin{array}{c}0.02 \\
{[.043]}\end{array}$ & $\begin{array}{c}36 \\
{[68.1]}\end{array}$ & $\begin{array}{c}0.02 \\
{[.056]}\end{array}$ \\
\hline Dairy & $\begin{array}{c}1 \\
{[7.4]}\end{array}$ & $\begin{array}{c}0.00 \\
{[.0031]}\end{array}$ & $\begin{array}{c}19 \\
{[56.6]}\end{array}$ & $\begin{array}{c}0.01 \\
{[.039]}\end{array}$ \\
\hline Fats & $\begin{array}{c}26 \\
{[20.4]}\end{array}$ & $\begin{array}{c}0.13 \\
{[.095]}\end{array}$ & $\begin{array}{c}23 \\
{[16.3]}\end{array}$ & $\begin{array}{c}0.13 \\
{[.090]}\end{array}$ \\
\hline Calories & $\begin{array}{c}1805 \\
{[591.7]}\end{array}$ & -- & $\begin{array}{c}1710 \\
{[517.4]}\end{array}$ & -- \\
\hline Observations & 644 & 644 & 649 & 649 \\
\hline
\end{tabular}

Notes: Standard deviations in brackets. All consumption figures are in grams per capita. Calorie share is the percent of total calories attributable to the particular food category. 
Table 5. Effect of the Price Increases on Calories

\begin{tabular}{|c|c|c|c|c|c|c|c|}
\hline & \multicolumn{7}{|c|}{ HUNAN } \\
\hline & (1) & (2) & (3) & (4) & (5) & (6) & (7) \\
\hline & \multirow[b]{2}{*}{$\begin{array}{c}\text { Per } \\
\text { Capita }\end{array}$} & \multicolumn{2}{|c|}{ Children (0-16) } & \multicolumn{2}{|c|}{ Adults (17-59) } & \multicolumn{2}{|c|}{ Elderly $(60+)$} \\
\hline & & Male & Female & Male & Female & Male & Female \\
\hline April & $\begin{array}{l}1803.0 \\
(23.6)\end{array}$ & $\begin{array}{l}1590.5 \\
(70.0)\end{array}$ & $\begin{array}{l}144.3 \\
(52.3)\end{array}$ & $\begin{array}{c}2041.0 \\
(31.2)\end{array}$ & $\begin{array}{c}1764.6 \\
(27.8)\end{array}$ & $\begin{array}{l}1812.0 \\
(50.4)\end{array}$ & $\begin{array}{c}1534.8 \\
(41.7)\end{array}$ \\
\hline December & $\begin{array}{l}1809.4 \\
(22.7)\end{array}$ & $\begin{array}{l}1706.6 \\
(68.2)\end{array}$ & $\begin{array}{l}1572.8 \\
(53.6)\end{array}$ & $\begin{array}{c}2079.4 \\
(41.7)\end{array}$ & $\begin{array}{c}1797.8 \\
(25.6)\end{array}$ & $\begin{array}{l}1855.7 \\
(45.1)\end{array}$ & $\begin{array}{c}1553.5 \\
(37.9)\end{array}$ \\
\hline Difference & $\begin{array}{c}6.4 \\
(32.8)\end{array}$ & $\begin{array}{l}116.1 \\
(97.8)\end{array}$ & $\begin{array}{c}128 \\
(74.8)\end{array}$ & $\begin{array}{c}38.4 \\
(52.1)\end{array}$ & $\begin{array}{c}33.1 \\
(37.8)\end{array}$ & $\begin{array}{c}43.6 \\
(67.6)\end{array}$ & $\begin{array}{c}18.7 \\
(56.4)\end{array}$ \\
\hline \multirow[t]{4}{*}{ Number of Obs. } & 632 & 105 & 117 & 509 & 547 & 162 & 217 \\
\hline & \multicolumn{7}{|c|}{ GANSU } \\
\hline & & \multicolumn{2}{|c|}{ Children (0-16) } & \multicolumn{2}{|c|}{ Adults (17-59) } & \multicolumn{2}{|c|}{ Elderly $(60+)$} \\
\hline & Capita & Male & Female & Male & Female & Male & Female \\
\hline April & $\begin{array}{l}1710.2 \\
(20.4)\end{array}$ & $\begin{array}{l}1501.6 \\
(49.1)\end{array}$ & $\begin{array}{l}1369.0 \\
(41.1)\end{array}$ & $\begin{array}{c}2005.7 \\
(27.8)\end{array}$ & $\begin{array}{l}1681.9 \\
(22.0)\end{array}$ & $\begin{array}{l}1772.1 \\
(77.2)\end{array}$ & $\begin{array}{r}1409.9 \\
(39.7)\end{array}$ \\
\hline December & $\begin{array}{l}1628.7 \\
(18.8)\end{array}$ & $\begin{array}{l}1485.9 \\
(39.2)\end{array}$ & $\begin{array}{l}1388.4 \\
(38.9)\end{array}$ & $\begin{array}{l}1866.0 \\
(22.5)\end{array}$ & $\begin{array}{l}1610.0 \\
(20.6)\end{array}$ & $\begin{array}{l}1711.3 \\
(69.9)\end{array}$ & $\begin{array}{l}1368.1 \\
(40.3)\end{array}$ \\
\hline Difference & $\begin{array}{c}-81.5^{* * *} \\
(27.8)\end{array}$ & $\begin{array}{l}-15.6 \\
(62.8)\end{array}$ & $\begin{array}{c}19.4 \\
(56.5)\end{array}$ & $\begin{array}{c}-139.8^{* * *} \\
(35.8)\end{array}$ & $\begin{array}{l}-72.0^{* *} \\
(30.2)\end{array}$ & $\begin{array}{c}-60.9 \\
(104.1)\end{array}$ & $\begin{array}{l}-41.8 \\
(56.6)\end{array}$ \\
\hline Number of Obs. & 641 & 179 & 158 & 567 & 576 & 63 & 158 \\
\hline
\end{tabular}


Table 6. Effect of the Price Increases on Consumption Patterns: Consumption Per Capita

\begin{tabular}{|c|c|c|c|c|c|c|}
\hline & \multicolumn{3}{|c|}{ HUNAN } & \multicolumn{3}{|c|}{ GANSU } \\
\hline & April & $\overline{\text { December }}$ & Difference & April & $\overline{\text { December }}$ & Difference \\
\hline Cereals & $\begin{array}{c}373.1 \\
(4.8)\end{array}$ & $\begin{array}{c}395.0 \\
(5.1)\end{array}$ & $\begin{array}{c}21.9^{* * *} \\
(7.0)\end{array}$ & $\begin{array}{c}383.7 \\
(5.2)\end{array}$ & $\begin{array}{c}356.4 \\
(4.4)\end{array}$ & $\begin{array}{c}-27.4^{* * *} \\
(6.8)\end{array}$ \\
\hline Meat and Dairy & $\begin{array}{l}47.2 \\
(2.8)\end{array}$ & $\begin{array}{l}40.7 \\
(2.5)\end{array}$ & $\begin{array}{l}-6.5^{*} \\
(3.7)\end{array}$ & $\begin{array}{l}31.3 \\
(2.5)\end{array}$ & $\begin{array}{l}30.5 \\
(2.4)\end{array}$ & $\begin{array}{c}-0.80 \\
(3.5)\end{array}$ \\
\hline Pulses & $\begin{array}{l}61.9 \\
(4.1)\end{array}$ & $\begin{array}{l}67.7 \\
(3.6)\end{array}$ & $\begin{array}{c}5.8 \\
(3.7)\end{array}$ & $\begin{array}{l}36.6 \\
(2.7)\end{array}$ & $\begin{array}{l}44.5 \\
(2.9)\end{array}$ & $\begin{array}{l}7.9^{* *} \\
(3.9)\end{array}$ \\
\hline Fruits and Vegetables & $\begin{array}{c}342.0 \\
(7.8)\end{array}$ & $\begin{array}{c}333.6 \\
(7.3)\end{array}$ & $\begin{array}{c}-8.4 \\
(10.7)\end{array}$ & $\begin{array}{c}232.1 \\
(5.6)\end{array}$ & $\begin{array}{c}266.5 \\
(5.3)\end{array}$ & $\begin{array}{c}34.4^{* * *} \\
(7.7)\end{array}$ \\
\hline Fats & $\begin{array}{l}26.0 \\
(0.8)\end{array}$ & $\begin{array}{l}21.8 \\
(0.7)\end{array}$ & $\begin{array}{c}-4.2^{* * *} \\
(1.1)\end{array}$ & $\begin{array}{l}23.4 \\
(0.6)\end{array}$ & $\begin{array}{l}24.5 \\
(0.6)\end{array}$ & $\begin{array}{l}1.1 \\
(0.9)\end{array}$ \\
\hline Number of Obs & 632 & 632 & 632 & 641 & 641 & 641 \\
\hline
\end{tabular}


Table 7. Effect of the Price Increases on Expenditure Patterns: Expenditures Per Capita

\begin{tabular}{|c|c|c|c|c|c|c|}
\hline & \multicolumn{3}{|c|}{ HUNAN } & \multicolumn{3}{|c|}{ GANSU } \\
\hline & April & $\overline{\text { December }}$ & Difference & April & $\overline{\text { December }}$ & Difference \\
\hline Food & $\begin{array}{l}74.7 \\
(1.6)\end{array}$ & $\begin{array}{l}77.3 \\
(1.4)\end{array}$ & $\begin{array}{c}2.6 \\
(2.1)\end{array}$ & $\begin{array}{l}63.5 \\
(1.3)\end{array}$ & $\begin{array}{l}68.4 \\
(1.2)\end{array}$ & $\begin{array}{c}4.9^{* * *} \\
(1.8)\end{array}$ \\
\hline Housing & $\begin{array}{c}5.9 \\
(0.9)\end{array}$ & $\begin{array}{l}10.3 \\
(4.1)\end{array}$ & $\begin{array}{c}4.4 \\
(4.2)\end{array}$ & $\begin{array}{c}6.1 \\
(0.7)\end{array}$ & $\begin{array}{c}5.3 \\
(0.5)\end{array}$ & $\begin{array}{l}-0.8 \\
(0.9)\end{array}$ \\
\hline Utilities & $\begin{array}{l}11.3 \\
(0.5)\end{array}$ & $\begin{array}{l}12.6 \\
(0.5)\end{array}$ & $\begin{array}{l}1.3^{*} \\
(0.7)\end{array}$ & $\begin{array}{c}8.1 \\
(0.3)\end{array}$ & $\begin{array}{c}9.8 \\
(0.2)\end{array}$ & $\begin{array}{c}1.7^{* * *} \\
(0.3)\end{array}$ \\
\hline Fuel & $\begin{array}{l}17.1 \\
(0.4)\end{array}$ & $\begin{array}{l}19.4 \\
(0.5)\end{array}$ & $\begin{array}{c}2.3^{* * *} \\
(0.6)\end{array}$ & $\begin{array}{l}23.7 \\
(0.7)\end{array}$ & $\begin{array}{l}35.6 \\
(1.3)\end{array}$ & $\begin{array}{c}11.9^{* * *} \\
(1.5)\end{array}$ \\
\hline Communications & $\begin{array}{c}6.2 \\
(0.6)\end{array}$ & $\begin{array}{c}5.1 \\
(0.3)\end{array}$ & $\begin{array}{l}-1.1 \\
(0.7)\end{array}$ & $\begin{array}{c}5.7 \\
(0.4)\end{array}$ & $\begin{array}{c}5.3 \\
(0.3)\end{array}$ & $\begin{array}{l}-0.5 \\
(0.5)\end{array}$ \\
\hline Transportation & $\begin{array}{l}4.0 \\
(0.4)\end{array}$ & $\begin{array}{c}3.5 \\
(1.0)\end{array}$ & $\begin{array}{l}-0.5 \\
(1.1)\end{array}$ & $\begin{array}{c}2.0 \\
(0.2)\end{array}$ & $\begin{array}{c}1.8 \\
(0.2)\end{array}$ & $\begin{array}{l}-0.2 \\
(0.3)\end{array}$ \\
\hline Health & $\begin{array}{l}74.5 \\
(7.1)\end{array}$ & $\begin{array}{c}85.2 \\
(18.5)\end{array}$ & $\begin{array}{c}10.7 \\
(19.8)\end{array}$ & $\begin{array}{l}37.2 \\
(5.1)\end{array}$ & $\begin{array}{l}24.6 \\
(3.0)\end{array}$ & $\begin{array}{c}-12.6^{* *} \\
(6.0)\end{array}$ \\
\hline Education & $\begin{array}{l}81.9 \\
(7.1)\end{array}$ & $\begin{array}{c}99.2 \\
(15.2)\end{array}$ & $\begin{array}{c}17.2 \\
(16.7)\end{array}$ & $\begin{array}{l}30.4 \\
(3.5)\end{array}$ & $\begin{array}{l}40.9 \\
(6.2)\end{array}$ & $\begin{array}{l}10.5 \\
(7.1)\end{array}$ \\
\hline Clothing & $\begin{array}{c}7.2 \\
(0.3)\end{array}$ & $\begin{array}{c}4.5 \\
(0.7)\end{array}$ & $\begin{array}{c}-2.7^{* * *} \\
(0.8)\end{array}$ & $\begin{array}{c}5.5 \\
(0.2)\end{array}$ & $\begin{array}{c}4.9 \\
(0.3)\end{array}$ & $\begin{array}{l}-0.6 \\
(0.4)\end{array}$ \\
\hline Alcohol/Tobacco & $\begin{array}{c}8.2 \\
(0.6)\end{array}$ & $\begin{array}{c}7.4 \\
(0.5)\end{array}$ & $\begin{array}{l}-0.8 \\
(0.8)\end{array}$ & $\begin{array}{c}3.3 \\
(0.4)\end{array}$ & $\begin{array}{c}3.2 \\
(0.2)\end{array}$ & $\begin{array}{l}-0.1 \\
(0.5)\end{array}$ \\
\hline Personal Items & $\begin{array}{c}5.0 \\
(0.2)\end{array}$ & $\begin{array}{c}5.2 \\
(0.2)\end{array}$ & $\begin{array}{c}0.2 \\
(0.3)\end{array}$ & $\begin{array}{c}2.9 \\
(0.2)\end{array}$ & $\begin{array}{c}3.7 \\
(0.2)\end{array}$ & $\begin{array}{c}0.8^{* * *} \\
(0.3)\end{array}$ \\
\hline Entertainment & $\begin{array}{c}2.6 \\
(0.1)\end{array}$ & $\begin{array}{c}1.9 \\
(0.2)\end{array}$ & $\begin{array}{c}-0.7^{* * *} \\
(0.2)\end{array}$ & $\begin{array}{c}1.6 \\
(0.3)\end{array}$ & $\begin{array}{c}0.6 \\
(0.1)\end{array}$ & $\begin{array}{c}-1.0^{* * *} \\
(0.1)\end{array}$ \\
\hline Number of Obs & 632 & 632 & 632 & 641 & 641 & 641 \\
\hline
\end{tabular}

Notes: Standard errors in parentheses. All numbers are nominal expenditures in yuan per capita. The columns marked "Difference" provide $t$-tests of the equality of means for the April and December consumption levels. *Significant at 10 percent level. ${ }^{* *}$ Significant at 5 percent level. ${ }^{* * *}$ Significant at 1 percent level. 
Figure 1. Changes in Household Calories Per Capita by Expenditure per Capita
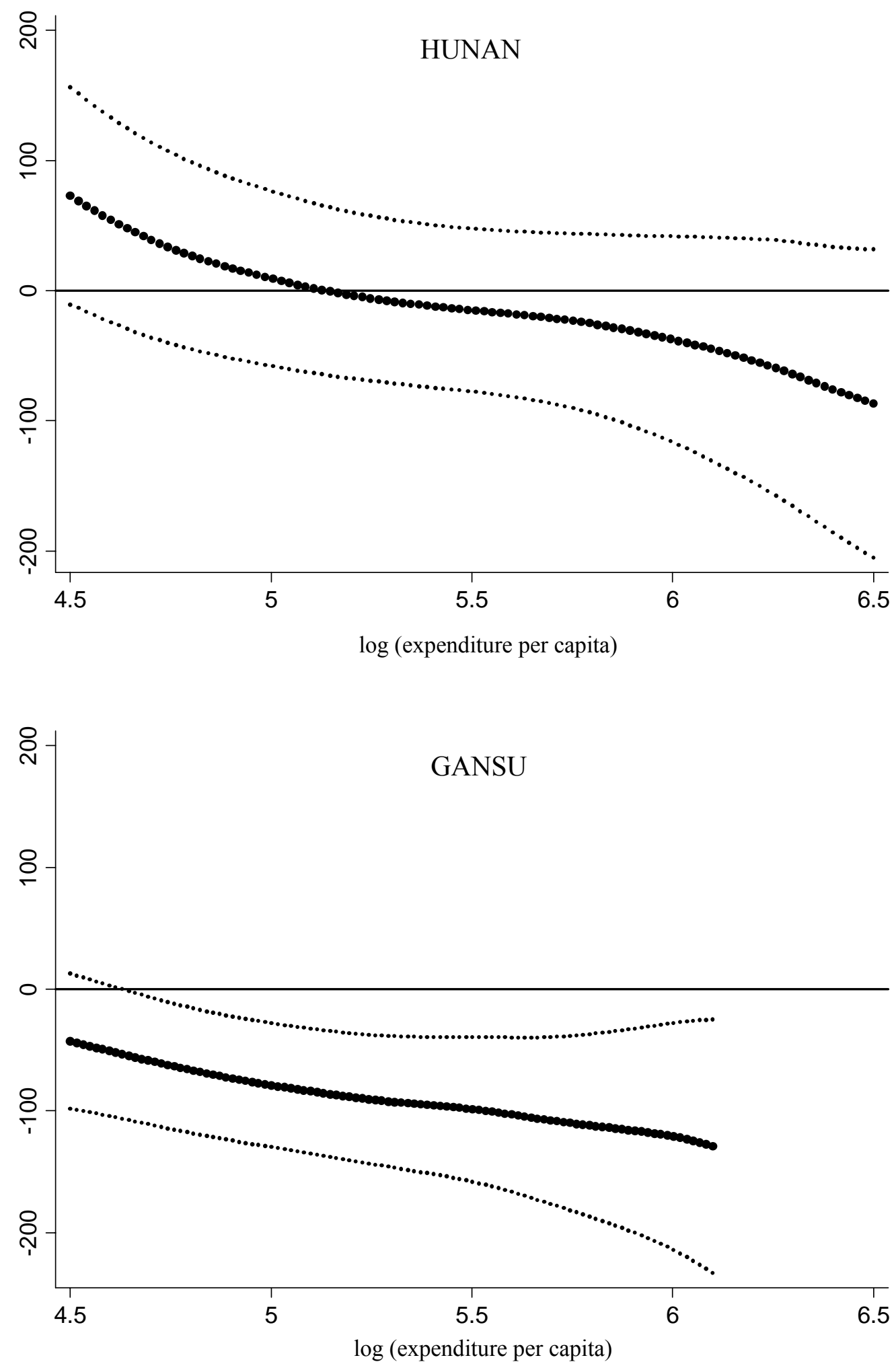